があったが, $d l$-メントールの生成量は $50 \%$ 以上に達し，銅-ク ロム触媒と同じ傾向を示するのと思われる。

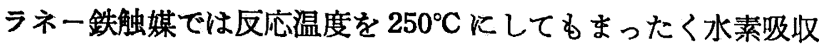
は認められなかった。

絹-パラジウム触媒る $180^{\circ} \mathrm{C}$ では水素の吸収は認められなかっ た。

\section{6 副反応生成物}

脱水反応に 基づくメンタンの生成は銅ークロ公触媒以外の 活性 の強い触媒では相当多量に達した。したがって，これらの触媒は 原料チモールおよび氷素を消費することが大きいので，工業的見 地からは好ましい触媒とはいいえない。銅ーク口ム触媒はメンタ ンの生成率がごく低いうえに，反応生成物も温度に上る変化がほ とんど認められないので，工業的使用に適しているものと考え る。
$3 \cdot 7$ 銅-クロムに他金属酸化物を添加した触媒の場合（表 6） 上記のように, 工業的使用に適した銅ークロム触媒に助触媒と して他の金属酸化物を添加することによって，dl-メントールの 生成率がいかに変化するかを検討した。その結果は表 6 に示す。

マンガンを加えた場合（No. 193～195）は銅ークロム触媒と似 た結果を示したが，タングステンを添加した場合(No. 196～198) は副反応の脱水反応が相当はげしく起こり,メンタンを多量に生 成した。またもリブデンを加えた場合（No. 199～201）には反応 速度が著しく遅く，未反応のチモールを相当残しているらえに， 副反応の脱水反応がはケ゚しく起こった。またカルシウム，バリウ ム、 マグネシウムの添加の影響は著しくないが，これらのうちで はバリウム添加のものがすぐれた結果を示している。

（昭和 36 年 4 月, 日化第 14 年会講演）

\title{
非イオン界面活性郕分子蒸留留分の起泡力および漫透力†
}

\author{
（昭 和 37 年 7 月 12 日受 理）
}

\section{田川清行・園田敏夫・大庭範秋 ${ }^{*}$}

\begin{abstract}
ノニルフェノールの平均 $7.5 \mathrm{~mol}$, オクチルフェノールの平均 $10 \mathrm{~mol}$, オレイルアルュールの平均 $7 \mathrm{~mol}$ の 3 種のェ チレンオキシド (EO) 付加物について分子蒸留を行ない, 得られた留分について水溶液の起泡力扰よび浸透力を測定し た。測定法として, 起泡力は Ross \& Miles 法と半微量 TK 法を, 浸透力は半微量ジク強制沈降法水平式を用いた。 測定温度は $25^{\circ} \mathrm{C}$, 測定濃度は $0.05 \sim 0.50 \%$ の範囲で行ない, $0.25 \%$ 濃度の值を代表值とした。

留分の起泡力は EO 付加モル数の増加とともに增大し，極大を経て漸減する傾向を示し，この傾向は留分と蒸留を行 なわないるのとで大差ない。

留分の泡の安定性および漫透力は蒸留を行なわないるのと同様に，ある EO 付加モル数でそれぞれ極大を示し，その 傾向は両者で大差ない。

起泡力, 泡の安定性, 浸透力に最適な EO 付加モル数は留分については 7〜9 の範囲にある。

留分の諸性質の值と重量百分率の積の総和から平均値を求め, 蒸留に供した試料の示す性質の值と比較したが，かなり 一致した結果が得られた。
\end{abstract}

\section{1 緒言}

前報1)の分子蒸留試験により,ノニルフェノールの平均 $7.5 \mathrm{~mol}$, オクチルフェノールの平均 $10 \mathrm{~mol}$, オレイルアルコールの平均 $7 \mathrm{~mol}$ のエチレンオキシド付加物 3 種について, 多数の留分を得 た。分子蒸留では精留効果を余り期待することはできないが，こ れらの留分が蒸留前の試料のエチレンオキシド付加モル数分布よ りも狭い分布を有するものと考えられるので，付加モル数分布が 非イオン界面活性凧の諸性質に及ぼす効果の一端を知るため, 各 留分の水溶液に拉ける起泡力および浸透力の測定を行なった。

また，得られた結果と留分と同じ親油性原料に，同一反応条件 下で合成して得られた種々の平均モル数のエチレンオキシド付加 物の性質とを比較し, 更に各留分の諸性質の値と重量百分率の積 の総和についてす検討を加えた。

†本報を「非イオン界面活性刻の分子蒸留之留分の性質に関 する研究 (第 2 報)」とする.

* 日本サーファクタント工業株式会社：東京都板橋区蓮根町.

1) 田川, 飯野, 太田, 工化 65, 1260 (1962).

2) 田川，飯野，園田，大庭，工化 65，949 (1962).

\section{2 実験}

$2 \cdot 1$ 試 料

(1) ノニルフェノールの平均 $7.5 \mathrm{~mol}$ エチレンオキシド付 加物 (NP-7.5) の分子蒸留留分：11 留分と残留物

（2）オクチルフェノールの平均 $10 \mathrm{~mol}$ エチレンオキシド付 加物 (OP-10) の分子蒸留留分: 14 留分と残留物

（3）オレイルフルコールの平均 $7 \mathrm{~mol}$ エチレンオキシド付 加物 (BO-7) の分子蒸留留分：17 留分と残留物

$2 \cdot 2$ 測定法

起泡力は Ross \& Miles 法 (RM 法) と半微量 TK 法 (TK 法）を併用し，浸透力は半微量ジスク強制沈降法水平式を用いて 測定を行なった。測定法, 測定条件等は既に報告 ${ }^{2,3,4)}$ したので省 略する。

\section{3 実験結果および考察}

\subsection{NP-7.5 の分子蒸留留分測定結果および考察}

3）田川, 飯野, 園田, 大庭, 工化 65,953 (1962).

4）田川, 飯野, 園田, 大庭, 工化 65，957 (1962), 
各留分について測定した結果を，表 1 に示す。表中の付加モル 数, 重量百分率は前報1) の值を, 起泡力, 泡の安定性, 浸透力の 值は $0.25 \%$ 濃度における值を比較のため, 代表值として記載し た。

表 1 NP-7.5 の分子蒸留留分測定結果

\begin{tabular}{|c|c|c|c|c|c|c|c|}
\hline \multirow[b]{2}{*}{ 留分 } & \multirow{2}{*}{$\begin{array}{l}\text { 付加モ } \\
\text { ル数 }\end{array}$} & \multirow{2}{*}{$\begin{array}{l}\text { 重量百 } \\
\text { 分神 }\end{array}$} & \multicolumn{2}{|c|}{ RM 法 } & \multicolumn{2}{|c|}{ TK 法 } & \multirow[b]{2}{*}{$\begin{array}{l}\text { 浸透力 } \\
\text { (sec) }\end{array}$} \\
\hline & & & $\begin{array}{l}\text { 泡高 } \\
\text { (mm) }\end{array}$ & $\begin{array}{c}\text { 安定性 } \\
(\%)\end{array}$ & $\begin{array}{l}\text { 泡其) } \\
\text { (\%) }\end{array}$ & $\begin{array}{c}\text { 安定性 } \\
(\%)\end{array}$ & \\
\hline 1 & 3.3 & 1.57 & 5 & 65 & 0 & 0 & 240 \\
\hline 2 & 4.2 & 6.00 & 9 & 90 & 0 & 0 & 338 \\
\hline 3 & 4.7 & 2.43 & 19 & 92 & 32 & 31 & 24.2 \\
\hline 4 & 5.0 & 5.18 & 25 & 99 & 98 & 96 & 15.3 \\
\hline 5 & 5.9 & 8.40 & 23 & 94 & 98 & 89 & 13.8 \\
\hline 6 & 6.6 & 6.60 & 37 & 93 & 98 & 85 & 14.5 \\
\hline 7 & 6.8 & 6.78 & 25 & 99 & 100 & 92 & 27.0 \\
\hline 8 & 7.4 & 9.46 & 42 & 97 & 98 & 99 & 44.0 \\
\hline 9 & 8.1 & 8.93 & 98 & 90 & 100 & 86 & 7.8 \\
\hline 10 & 8.3 & 14.21 & 138 & 91 & 98 & 79 & 5.3 \\
\hline 11 & 9.1 & 16.79 & 158 & 90 & 100 & 61 & 14.5 \\
\hline $\mathbf{R}$ & 10.3 & 13.65 & 139 & 94 & 100 & 65 & 57.0 \\
\hline
\end{tabular}

$3 \cdot 1 \cdot 1$ 起泡力 多種類の 非イオン界面活性剂の 起泡力2,3) を $\mathrm{RM}$ 法と TK 法の両測定法を用いて測定を行ない，その結果か らそれぞれの特色として， RM 法による泡高が試料間の起泡力の 比較に用いて有効であるのに対し，TK 法の泡量が試料間の相違 による変化が小さく，起泡力の比較には有効でなかったことを述 ベた。

本報においても，表 1 の TK 法による泡量については留分間 に有意差がほとんど認められていない。

表 1 の値から， RM 法の泡高とエチレンオキシド (以下 EO と 略す）付加モル数との関係を図 1 に示した。

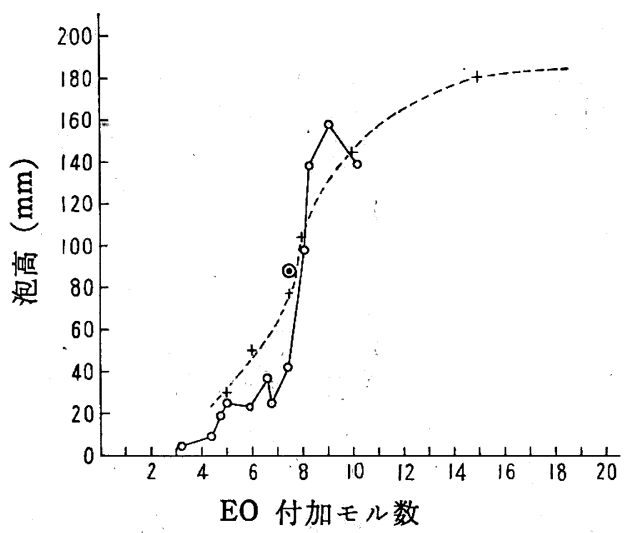

図 1 NP-7.5 の分子蒸留留分の泡高と EO 付加モル数との関係（RM 法）

図 1 中の実線は得られた各留分の泡高と EO 付加モル数との関 係，点線はノニルフェノールに直接 EO を付加重合させたもの (以下合成 $\mathrm{EO}$ 付加物と称す) の泡高と, $\mathrm{EO}$ 平均付加モル数と の関係を示したものである。この合成 EO 付加物は前報2の試料 および前報 ${ }^{2}$ と同一条件で合成した試料である。また，○印は各 留分の泡高と重量百分率の積について次式からその総和 $S_{\mathrm{F}}$ を計 算し，その值を EO $7.5 \mathrm{~mol}$ の所にプロットした点である。

$$
\begin{array}{cc} 
& S_{\mathrm{F}}=\sum_{i=1}^{n} H_{i} \cdot R_{i} / 100 \\
\text { ただし } & H_{i}: i \text { 番目の留分の泡高 }(\mathrm{mm}) \\
& R_{i}: i \text { 番目の留分の重量百分率 }
\end{array}
$$

図 1 から, 各留分の泡高および合成 $\mathrm{EO}$ 付加物の泡高はいずれ も $\mathrm{EO}$ 付加モル数の增加とともに増大する傾向を示しており，ま た両者とも EO 付加モル数の增加に対する泡高増加の割合がいち
じるしい部分が存在するが，勾配のちがいは付加モル数分布が両 者でちがうことと, 各成分の起泡力の差によって説明されるもの である。

$S_{F}$ の計算值は $88 \mathrm{~mm}$ であり，蒸留に供試した合成 $E O$ 付加 物 NP-7.5 の実測泡高 $77 \mathrm{~mm}$ と比較すると, 図 1 にみられる よ5にその差は余り大きくないことがわかる。

3.1.2 泡の安定性 $\mathrm{RM}$ 法と TK 法とを比較した場合, $\mathrm{RM}$ 法による泡の安定性は，試料の相違による变化が小さいのに反し， TK 法による泡の安定性は, 試料の相違に対応して変化が大きく 現われる特色を有し，試料間の安定性を比較するには TK 法を 用いることが有利であることを報告2)した。本報においても， $\mathrm{RM}$ 法の安定性の值の変化は小さいことが㒛められる。

表 1 の值から, 各留分の TK 法による泡の安定性々 EO 付加 モル数との関係を図 2 そ示した。

図 2 中の実線は留分の安定性を, 点線は合成 EO 付加物の安定 性を表わす。図から留分の安定性は EO 5〜8 mol 間で 85〜100 \%の值を示すが, EO $5 \mathrm{~mol}$ 以下, EO $8 \mathrm{~mol}$ 以上で悪くなって

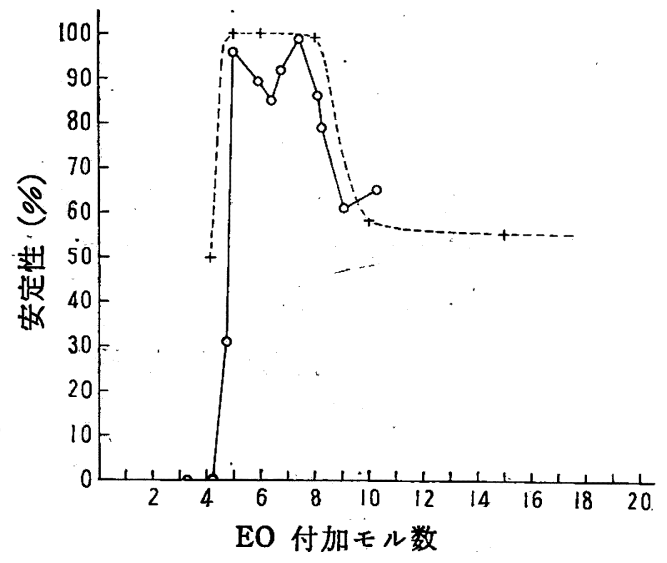

図 2 NP-7.5 の分子蒸留留分の安定性と EO 付加 モル数との関係 (TK 法)

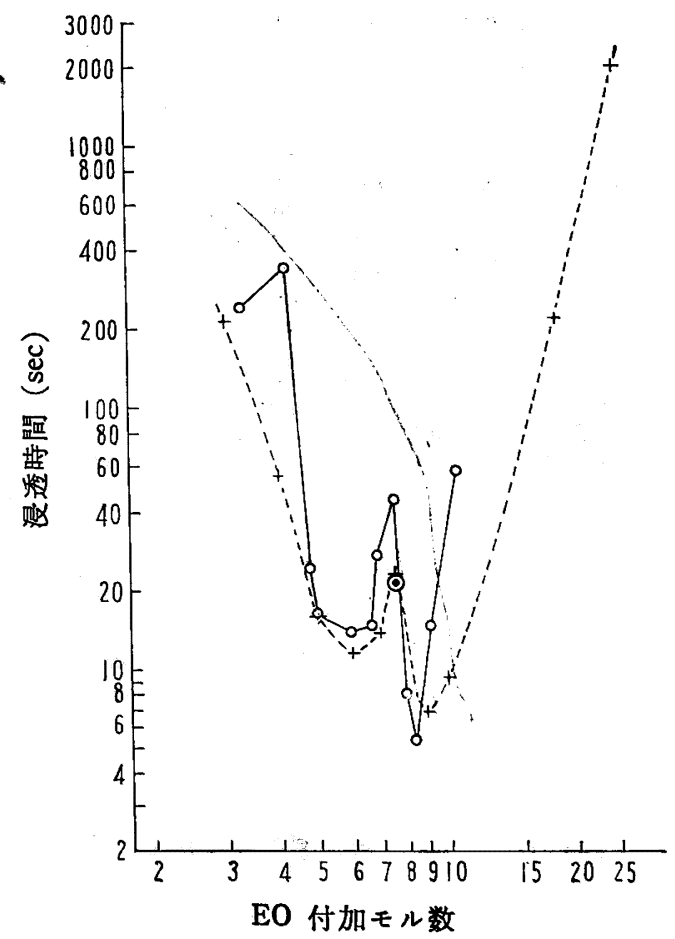

図 3 NP-7.5 の分子蒸留留分の浸透力と EO 付加モル数との関係 
いる。

$3 \cdot 1 \cdot 3$ 浸透力 表 1 の值から, 各留分の浸透力と EO 付加モ ル数との関係を両対数目盛で図 3 に示した。

図 3 中の実線は留分の浸透力を, 点線は合成 $\mathrm{EO}$ 付加物の浸透 力を表わす。四から，留分衫よび合成 EO 付加物ともに EO 8

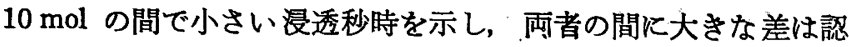
められない。

図中のの印は各留分の浸透秒時の対数值と重量百分率との積に ついて次式からその総和 $\left(\log S_{\mathrm{w}}\right)$ を求め, 浸透秒時 $S_{\mathrm{w}}$ を $\mathrm{EO}$ 付加モル数 7.5 の所にプロットした点である。

$$
\log S_{\mathrm{w}}=\sum_{i=1}^{n} \log t_{i} \cdot R_{i} / 100
$$

$t_{i}: i$ 番目の留分の浸透秒时

$R_{i}: i$ 番目の留分の重量百分率

$S_{\mathrm{w}}$ を表 1 から計算すると 21.2 秒となる。蒸留に 供試した NP-7.5 の実測浸透秒時は 22.8 秒であり, 図3からも両者がほ 々んど一致していることが認められる。

また起泡力, 泡の安定性, 浸透力に最適な付加モル数はそれぞ れほぼ 9，7，8 である（表 1 ，太字の数值に 相当する付加モル 数)。

\section{$3 \cdot 2$ OP-10 の分子蒸留留分測定結果および考察}

各留分について測定した起泡力, 泡の安定性, 浸透力は代表值 として $0.25 \%$ 濃度のものを, また $\mathrm{EO}$ 付加モル数, 重量百分率 は前報1)の值をあわせて表 2 に示す。

表 2 OP-10 の分子蒸留留分測定結果

\begin{tabular}{|c|c|c|c|c|c|c|c|}
\hline \multirow{2}{*}{ 留分 } & \multirow{2}{*}{$\begin{array}{l}\text { 付加モ } \\
\text { ル数 }\end{array}$} & & \multicolumn{2}{|c|}{ RM 法 } & \multicolumn{2}{|c|}{ TK 法 } & \multirow{2}{*}{$\begin{array}{l}\text { 湜透力 } \\
(\mathrm{sec})\end{array}$} \\
\hline & & 分 率 & $\begin{array}{l}\text { 泡高 } \\
\text { (mm) }\end{array}$ & $\begin{array}{c}\text { 安定性 } \\
(\%)\end{array}$ & $\begin{array}{l}\text { 泡貫 } \\
(\%)\end{array}$ & $\begin{array}{c}\text { 安定件 } \\
(\%)\end{array}$ & \\
\hline 1 & 4.3 & 4.37 & 75 & 72 & 100 & 38 & 11.5 \\
\hline 2 & 5.8 & 4.93 & 80 & 94 & 100 & 60 & 9.5 \\
\hline 3 & 6.9 & 5.59 & 126 & 94 & 100 & 63 & 10.8 \\
\hline 4 & 7.3 & 3.66 & 135 & 91 & 100 & 45 & 7.4 \\
\hline 5 & 8.3 & 6.62 & 183 & 77 & 100 & 41 & 7.0 \\
\hline 6 & 8.9 & 9.59 & 209 & 91 & 100 & 48 & 7.6 \\
\hline 7 & 9.5 & 6.98 & 193 & 92 & 98 & 42 & 7.6 \\
\hline 8 & 9.8 & 4. 30 & 189 & 90 & 98 & 44 & 12.1 \\
\hline 9 & 10.6 & 6.65 & 196 & 93 & 100 & 47 & 22.5 \\
\hline 10 & 10.9 & 8.70 & 186 & 91 & 100 & 44 & 26.8 \\
\hline 11 & 11.4 & 5.73 & 165 & 91 & 98 & 46 & 29.7 \\
\hline 12 & 11.6 & 4.83 & 170 & 90 & 100 & 47 & 43.0 \\
\hline 13 & 11.9 & 4.55 & 173 & 89 & 100 & 51 & 65.0 \\
\hline 14 & 12.3 & 10.74 & 164 & 91 & 100 & 53 & 65.0 \\
\hline $\mathbf{R}$ & 14.6 & 12.76 & 188 & 92 & 96 & 42 & 175 \\
\hline
\end{tabular}

3.2・1 起泡力 $\mathrm{TK}$ 法の泡量は各留分についてほとんど変化 が認められない。表 2 の值から各留分の RM 法による泡高と EO 付加モル数との関係を図 4 に示した。

図 4 から EO 付加モル数増加にともない泡高も増加するが，EO $9 \mathrm{~mol}$ 近辺でほほ極大に達し, $9 \mathrm{~mol}$ 以上では徐々に減少する傾 向がみられる。また，EO 6〜9 mol 間における留分の泡高の增加 （実線）が，合成 EO 付加物の泡高の増加（点線）よりもその勾 配が大であることは，NP の場合と同様に試料間の EO 付加モル 数分布の差異によるものと思われる。

また， $S_{\mathrm{F}}$ を計算すると $169 \mathrm{~mm}$ となり，蒸留に供試した合成 EO 付加物 OP-10 の泡高の実測值 $164 \mathrm{~mm}$ とほとんど一致して いる。

留分の EO 付加モル数 $9 \mathrm{~mol}$ と $3 \cdot 1 \cdot 1$ の NP-7.5 の留分 EO $9 \mathrm{~mol}$ と比較すると，OP の留分の方がかなり泡高が大きい。合

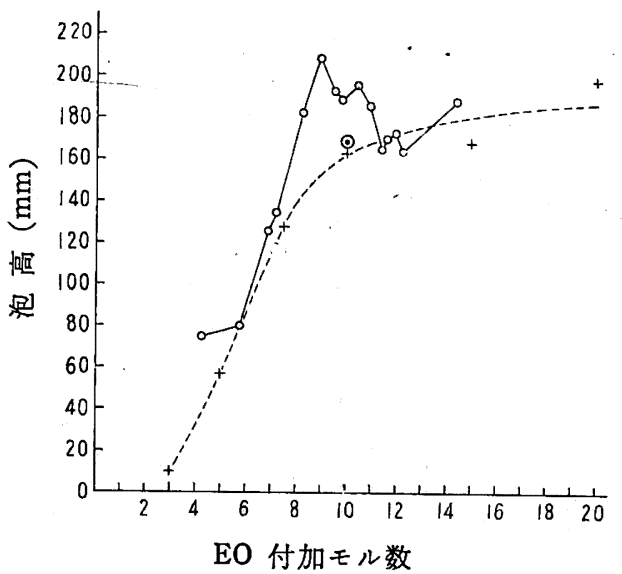

図 4 OP-10 の分子蒸留留分の泡高と EO 付加モル数との関係 ( $\mathrm{RM}$ 法)

成 EO 付加物については, NP-9 と OP-9 の泡高に大きな差が みられなかったが，留分についてみられる差異は NP と OP の アルキル鎖の構造が異なること，および蒸留に供した試料の EO 付加モル数が NP は $7.5 \mathrm{~mol}, \mathrm{OP}$ は $10 \mathrm{~mol}$ であることなどに よるものと思われる。

3.2.2 泡の安定性 RM 法による留分の安定性の变化は 3.1・ 2 と同様に, 留分間の差が小さい。表 2 の值から, TK 法による 留分の安定性と EO 付加モル数との関係を図 5 に示した。

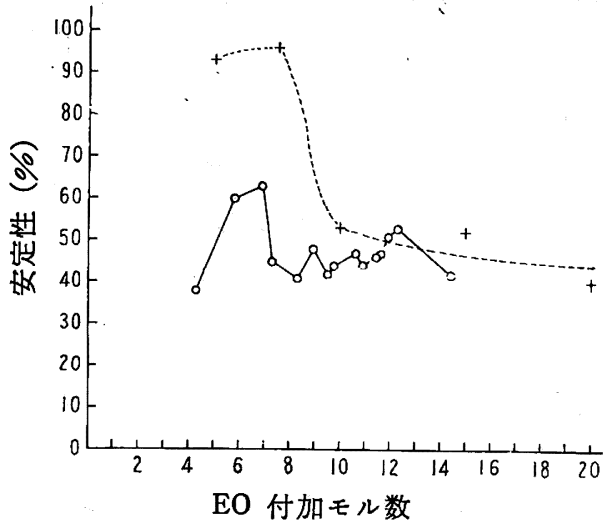

図 5 OP-10 の分子蒸留留分の泡の安定性と EO 付加モル数との関係（TK 法）

図 5 から，各留分の安定性は総体的に悪く，安定性の比較的よ いEO 付加モル数 5 7 の間でも 60〜65\% 程度であり，図 1 の NP-7.5 の留分の安定性 が EO 付加モル 数 5〜8 で 85〜100\% の值を示しているのに比べ, 安定性にかなりの開さがある。この 開きは原料のノニルフェノールとオクチルフェノールの炭素数, アルキル鎖の構造の差に原因するものと推察される。また，留分 の安定性は，合成 $\mathrm{EO}$ 付加物の安定性に比して悪いが，变化の傾 向はやや似ていることが認められる。

$3 \cdot 2 \cdot 3$ 浸透力 表 2 の各留分の浸透秒時と EO 付加モル数と の関係を両対数目盛で図 6 亿示した。

図 6 から, EO 7〜10 mol の間に極小浸透秒時が存在するが, 留分の示す浸透秒時 (実線) は合成 EO 付加物 (点線) の上方に 存在して扣り，留分の浸透力は全体に劣っていることがわかる。

各留分の值から $S_{\mathrm{w}}$ を計算すると, 13.7 秒となり, 蒸留に供 試した OP-10 の実測浸透秒時 10.0 秒と比較してかなりの一致 がみられた。 


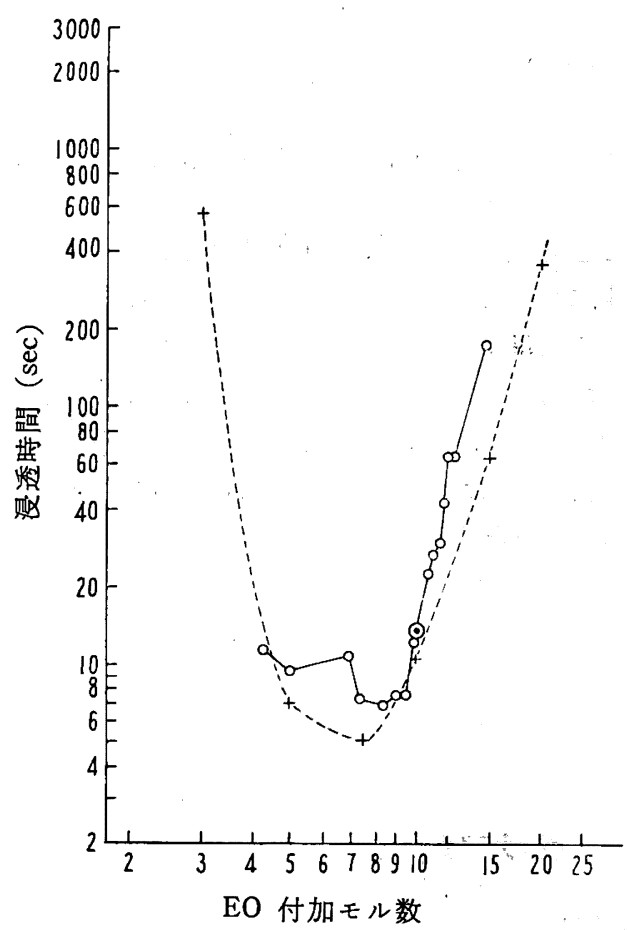

目 6 OP-10 の分子蒸留留分の浸透力と $\mathrm{EO}$ 付加モル数との関係

また起泡力, 泡の安定性, 浸透力の最適な付加モル数はそれぞ れほぼ 9，7，8 である(表 2 ，太字参照）。

\subsection{B0-7 の分子蒸留留分測定結果および考察}

各留分について得られた結果を，表 3 に示す。表中の付加モル 数, 重量百分率(前報 ${ }^{1)}$ の值を, 起泡力, 泡の安定性, 浸透力の 值は $0.25 \%$ 濃度の值を代表值として記載した。

表 3 BO-7 の分子蒸留留分測定結果

\begin{tabular}{|c|c|c|c|c|c|c|c|}
\hline \multirow{2}{*}{ 留分 } & \multirow{2}{*}{$\begin{array}{l}\text { 付 加 } \\
\text { モル数 }\end{array}$} & \multirow{2}{*}{$\begin{array}{l}\text { 重 量 } \\
\text { 百分率 }\end{array}$} & \multicolumn{2}{|c|}{ RM 法 } & \multicolumn{2}{|c|}{ TK 法 } & \multirow[b]{2}{*}{$\begin{array}{l}\text { 漫透力 } \\
(\mathrm{sec})\end{array}$} \\
\hline & & & $\begin{array}{c}\text { 泡高 } \\
\text { (mm) }\end{array}$ & $\begin{array}{l}\text { 安定性 } \\
(\%)\end{array}$ & $\begin{array}{l}\text { 泡量 } \\
(\%)\end{array}$ & $\begin{array}{c}\text { 安定性 } \\
(\%)\end{array}$ & \\
\hline 1 & 1.0 & 3.53 & 4 & 77 & 0 & & 232 \\
\hline 2 & 1.2 & 4.05 & 8 & 100 & 0 & & 174 \\
\hline 3 & 2.5 & 5.23 & 9 & 100 & 0 & & 1280 \\
\hline 4 & 2.7 & 1.56 & 11 & 100 & 0 & & 2400 \\
\hline 5 & 3.3 & 1.94 & 18 & 86 & 0 & . & 262 \\
\hline 6 & 3.9 & 3.19 & 15 & 100 & 100 & 65 & 400 \\
\hline 7 & 4.5 & 3.88 & 15 & 90 & 100 & 64 & 298 \\
\hline 8 & 4.9 & 3.12 & 16 & 100 & 98 & 77 & 195 \\
\hline 9 & 5.5 & 4.05 & 20 & 99 & 100 & 54 & 320 \\
\hline 10 & 6.1 & 3.36 & 56 & 96 & 100 & 74 & 570 \\
\hline 11 & 6.5 & 3.74 & 75 & 89 & 98 & 87 & 86 \\
\hline 12 & 6.9 & 3.22 & 112 & 90 & 100 & 78 & 87 \\
\hline 13 & 7.2 & 5.62 & 144 & 94 & 98 & 91 & 84 \\
\hline 14 & 7.7 & 4.78 & 175 & 92 & 100 & 83 & .73 \\
\hline 15 & 8.7 & 9.58 & 189 & 91 & 96 & 93 & 89 \\
\hline 16 & 9.1 & 4.82 & 180 & 93 & 98 & 83 & 89 \\
\hline 17 & 11.2 & 24.77 & 184 & 92 & 100 & 68 & 173 \\
\hline $\mathbf{R}$ & 12.7 & 9.56 & 165 & 92 & 94 & 62 & 870 \\
\hline
\end{tabular}

3.3.1 起泡力 各留分の $\mathrm{TK}$ 法の泡量は留分 5 までは 0 であ るが, 留分 6〜17 および残留物では 95〜100\% の值を示し, 留 分間の差はほとんどない。表 3 の值から各留分の RM 法の泡高 と EO 付加モル数との関係を図 7 に示した。

図 7 から, 留分の $\mathrm{EO}$ 付加モル数 $6 \mathrm{~mol}$ 以下に护る泡高の 変化は小さいが, EO 6〜9 $\mathrm{mol}$ では, 泡高が $\mathrm{EO}$ 付加モル数の 增大に対して著しく大となり, $9 \mathrm{~mol}$ 以上では漸减の傾向がみら れる。

EO 付加モル数に対し泡高の急增する様子は, 留分および合成

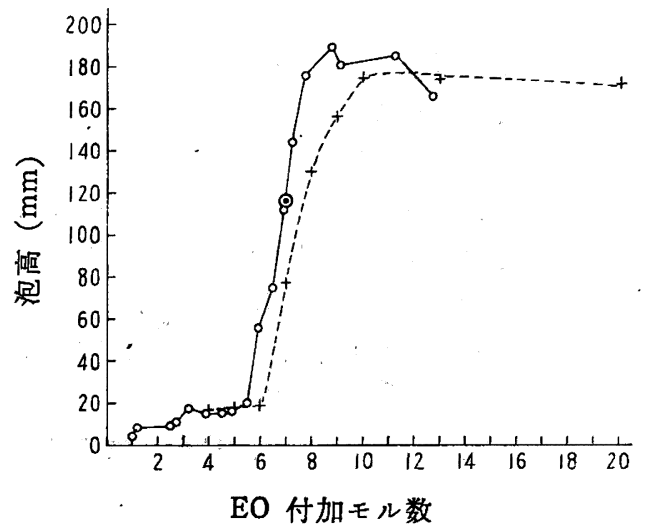

図 7 BO-7 の分子蒸留留分の起泡力と EO 付加モ儿数との関係（RM 法）

EO 付加物とも大体同様である。

$S_{\mathrm{F}}$ を計算すると $116 \mathrm{~mm}$ となり，蒸留に 供試した BO-7 の 実測泡高 $77 \mathrm{~mm}$ と比較してかなりの開きがある。前述の NP7.5, OP-10 では，その差が小さかったことから考えて，前報1) にみられるような, 付加モル数分布の相違による加成性不成立の 影響が現われているものと推察される。

3.3.2 泡の安定性 RM 法による安定性は留分間の差が小さ く, 90〜 100\% の值を示している。表 3 の値から, TK 法による 安定性と EO 付加モル数との関係を図 8 に示した。

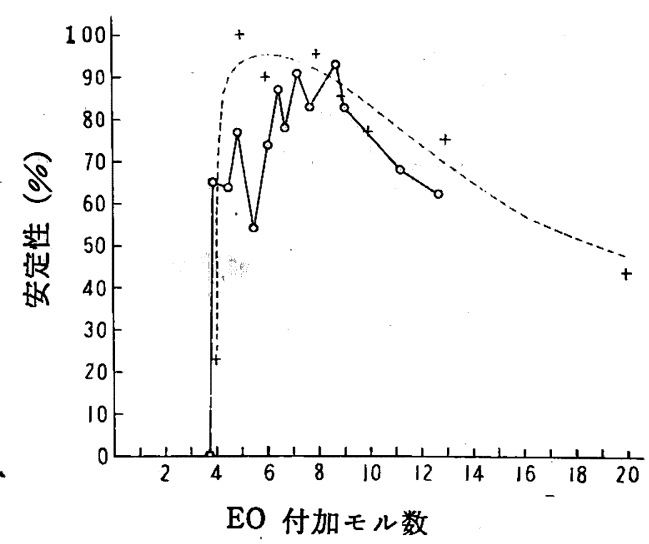

図 8 BO-7 の分子蒸留留分の泡の安定性と EO 付加モル数との関係 (TK 法)

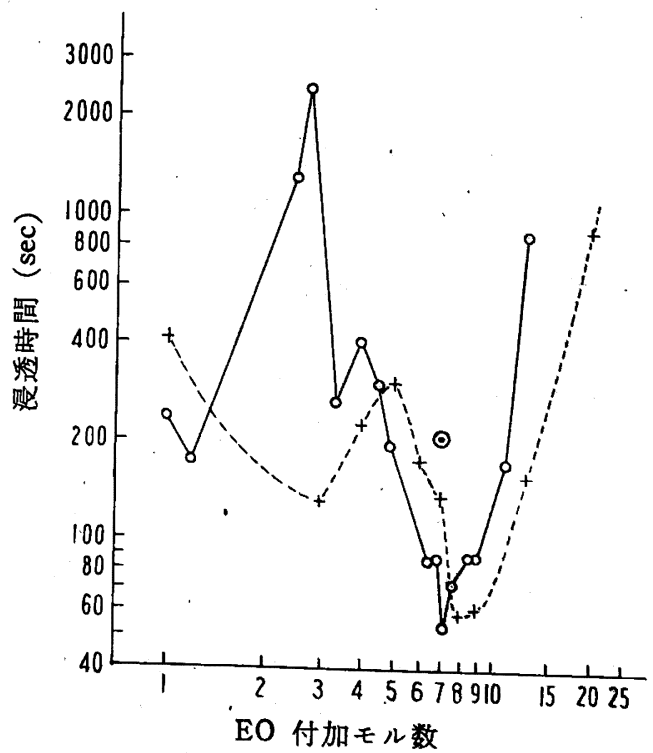

図 9 BO-7 の分子蒸留留分の浸透力と EO 付加モル数との関俰 
因 8から, 留分の安定性は EO 6 9 mol の間によいところが あり, EO $6 \mathrm{~mol}$ 以下, EO $9 \mathrm{~mol}$ 以上で悪くなっている。

各留分拉よび合成 $\mathrm{EO}$ 付加物の安定性は大体同様な变化を示し ておりまた $3 \cdot 1.2$ および $3 \cdot 2 \cdot 2$ とも同様な傾向をもつ。

$3 \cdot 3 \cdot 3$ 浸透力 表 2 の各留分の漫透秒時と EO 付加モル数と の関係を両対数目盛で因 9 に示した。

図 9 から,オレイルアルコールの $\mathrm{EO}$ 付加物はノニルフェノー ル，オクチルフェノールの EO 付加物に比して浸透力は劣って抹 り，留分の $\mathrm{EO}$ 付加モル数 6 9 の間で浸透秒時の極小が認めら れ，その極小值は点線で示される合成 $\mathrm{EO}$ 付加物の值と大体に扝 いてー致している。

$S_{\text {w }}$ を計算すると 208 秒となり、蒸留に供した BO-7 の実測 浸透秒時 136 秒と比較するとかなり差がみられる。前述した NP-
7.5，OP-10 では，これら值間の差が非常に小さいことと比較し て3.3.1で述べたような付加モル数分布の相違による加成性不成 立の影響が現われているものと考兄られる。

また起泡力, 泡の安定性, 浸透力の最適な付加モ儿数はそれぞ れほぼ 9,9，7 である。

以上のことから，NP，OP，BO のそれぞれについて，起泡力， 泡の安定性, 浸透力の最適值を与える $\mathrm{EO}$ 付加モル数はいずれも ほぼ 7〜9 の範囲に存在することがわかった。

また，起泡力および泡の安定性の测定法の特徽について， RM 法が起泡力の測定に, TK 法が泡の安定性の測定に適しているこ とを既に報告2,s) したが，分子蒸留を行なった䧕料についても同 様であることを確かめ得た。

\title{
アセトキシアントラセンのクロマトクラフ酸化†
}

（昭 和 37 年 5 月 10 日 受 理）

\section{船久保 英一・永 井 利一・下田 啓太郎*}

\begin{abstract}
9-アセトキシフントラセン，9,10-ジアセトキシアントラセン，オキシアントロンアセテート等が，いずれる，アルミ ナによりフントラキノンに酸化されるが, シリカゲルではほとんど変化しない事実を見出した。

一方, これらの化合物は, 酸には比較的安定であるが, 微量のアルカリの存在で容易にアントラキノンに酸化されると

い5知見を得, この場合, $\mathrm{OH}^{-}$攻撃と $\mathrm{H}^{-}$脱離によるアルカリ酸化機構で解釈した。

アルミナ,シリカゲルの吸着性並びに反応性に及ぼす差異は, その塩基性, 酸性の概念で理解される。

すなわち、アルミナにおいては, 溶質分子が電子供与体として $\mathrm{Al}^{+}$に配位し, これにアルミナの有する $\mathrm{OH}^{-} か ゙$ 攻撃 することにより, 酸化されるが, シリカゲルでは, その表面シラノールのHが強い酸性度を示す結果, 吸着性は大きくて る変質しない。
\end{abstract}

\section{1 緒 言}

クロマトグラフ用の代表的な吸着剤であるアルミナやシリカゲ ルに対する芳香族化合物の吸着性は，吸着郕を電子受容体，溶質 を電子供与体とする化学吸着と認められており,これらの吸着剂 に対する溶質の分子構造による吸着性の差異に基ついてて, 物質を 分離精製する方法はクロマトグラフ法と呼ばれて広く利用されて いることは周知の通りである。

ところが場合によっては，クロマトグラフ操作によって溶質が 精製されるどころか，他の物質に变化する事実るかなり認められ ている。

しかしこのようなクロマトグラフ变質現象そのむのの機構に ついては余り研究がなされていない。

著者らは，先に，N-アセチルカルバジールがアルミナにより 分解されてカルパゾールを生成し，シリカゲルによっては何ら変 化をうけない現象を見出し，变質の原因としては，アルミナが機 械的に有する不純物が夜相に放出されて起る純然たる有機化学的 反応ではなくて，一つの接触反応であることを認め，その場合反 応性に及活すアルミナとシリカゲルとの差異をとの塩基性と酸性

† 本報を「カラムクロマトタラフィーの理論と実際（第 14 報)」とする。第 13 報は船久保, 永井, 吉田, 友田, 工化 65,1560 (1962).

* 大阪大学工学部応用理学講座 : 大阪市都島区東野田.
を考虑して解釈しだ1)。

その後, 著者らは，この種変質の新例として，アセトキシアン トラセン類が，やはりアルミナにより变質するが，シリカゲルで は変質しない現象を見出した。

しかし，この場合には，N-アセチルカルバジールで見出され たようなアセチル基の脱離のみでなく，更に酸化を伴った変質物 であるアントラキノンが生成することを認めた。

このような酸化を伴 5変質現象が, 先りに述べたアルミナ, シ リカゲルの塩基性, 酸性の概念で解釈し得るかどうかを検討した 結果を記述した。

\section{2 実 験 の 部}

\section{$2 \cdot 1$ 試料の調製}

アントロン 既報)と同一法により合成したもの。 $\mathrm{mp}$ 155〜 $158^{\circ} \mathrm{C}$ 。

9-アセトキシアントラセン Fieser らの方法3)とより, アント ラセンを四酶酸鉛で酸化して合成した。 $\mathrm{mp} 132 \sim 133^{\circ} \mathrm{C}, \mathrm{C} 80.61$ $\%, \mathrm{H} 5.23 \%$ (計算値 C $81.34 \%$, H $5.12 \%$ )。

） 船久保, 永井, 守谷, 工化 $65 ， 782$ (1962).

2) 永井, 船久保, 工化 64, 1053 (1961).

3) L. Fieser, S. T. Putnum, J. Am. Chem. Soc. 69, 1038 (1947). 